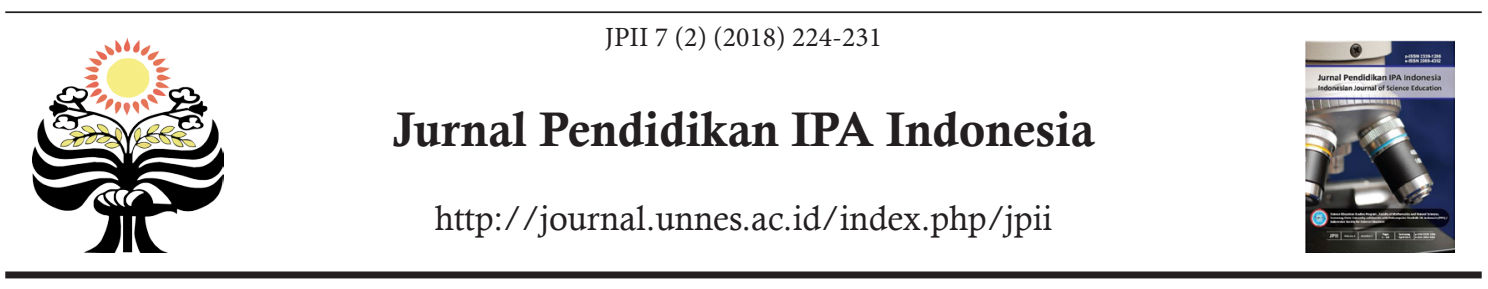

\title{
SPATIAL INTELLIGENCE AND STUDENTS' ACHIEVEMENT TO SUPPORT CREATIVITY ON VISUOSPATIAL-BASED LEARNING
}

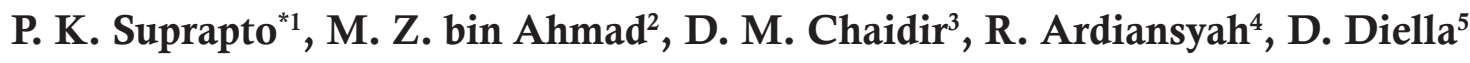 \\ ${ }^{1,3,4,5}$ Biology Education Department, Faculty of Teacher Training and Education, Universitas Siliwangi \\ ${ }^{2}$ School Of Educational Studies, Universiti Sains Malaysia
}

DOI: 10.15294/jpii.v7i2.14322

Accepted: March 14 ${ }^{\text {th }}, 2018$. Approved: May 27 ${ }^{\text {th }}, 2018$. Published: June $30^{\text {th }}, 2018$

\begin{abstract}
This research intended to know how the students' spatial intelligence and achievement supported the creativity of prospective teachers. This study was conducted on the subject of plant anatomy with visuospatial-based learning. The visuospatial-based learning model used in this study is called the wimba learning model. The method of this research was a quantitative /quasi-experiment with the pre- and post-test group design. The population was fourth-semester students in four classes of Biology Education who took Plant Anatomy course in 2017 in a university situated a small town, West Java, Indonesia. The sample of this research was two classes picked using the purposive sampling regarding their homogenous sampling of having the relatively same ability. The treatments for each class was that the use of the deductive and inductive approach. The variables measured were spatial intelligence, students' achievement and creativity of TCIA (Test of Creative Imagery Abilities). The data processing adopting multiple correlation tests with SPSS was to see the relationship between the variables. The results showed that spatial intelligence and students' achievement could support creativity at a moderate level, indicated by the value of $R_{\text {deductive }}=0,451$ and $R_{\text {inductive }}=0,474, R_{\text {inductive }}>R_{\text {deductive, }}$ which meant that the inductive approach was better to support creativity. In conclusion, spatial intelligence and students' achievement could support creativity, especially in the inductive approach. The results of this study could be useful to improve the creativity of prospective biology teachers.
\end{abstract}

(C) 2018 Science Education Study Program FMIPA UNNES Semarang

Keywords: creativity, spatial intelligence, students' achievement, wimba learning model

\section{INTRODUCTION}

Facing the era of globalization, we should be ready to produce creative and innovative students. Teachers should plan student-centered learning to foster the spirit of learning, motivation, creativity, initiative, innovation, and independence (Fatimah, 2015). In general, learning process either at school or college based only on cognitive. We have forgotten that our children need to improve other intelligence such as spatial, natural, interpersonal, kinesthetic, mathematical and some others. We also believe that there is a

*Correspondence Address

E-mail: purwatik1@gmail.com correlation between intelligence and creativity (Jauk et al., 2013).Some students said that learning plant anatomy is quite boring and difficult to understand; therefore, it is necessary to develop an interesting plant anatomy learning. In fact, studying plant anatomy could develop students' spatial intelligence. Thus, plant anatomy learning should be delivered using a visuospatial-based learning model. The visuospatial-based learning model here is the wimba learning model. This model enables students to be active and independent; also, forces students to make microscopic representation and imagine it in the form of three dimensions (3D) features. As the result, students will have a better understanding of cells, tissu- 
es, and organs phenomena in plants. This is in accordance with Bolotin \& Nashon (2012) who stated that spatial intelligence is very important to understand phenomena. In fact, only a few students and a small number of graduate students have the opportunity to develop this skill at an adequate level. Spatial intelligence is one of the intelligence that enables one to visualize information and synthesize data and concepts into visual metrics or images. Ramadas (2009) stated that visual and spatial thinking is an integral part of learning science, which is a simplification of complex natural phenomena expressed in concrete, visual or symbolic models. Visuospatial thinking and concept cannot be separated from the process of imagination that has an impact on creativity. Kell et al (2013) stated that spatial ability has a unique role in the development of creativity. Without spatial intelligence, creative thinking and innovative production are incomplete. Improving spatial ability could be achieved by changing one representation to another, just like turning 2D (dimension) representation features into concrete $3 \mathrm{D}$ features. These representational skills include the ability to analyze representation features, convert one representation into another, and generate new representations. This activity intends to explain the usefulness of certain representations and explain the uniqueness of different representations (Stieff et al., 2016). Visuospatial representation activities could improve spatial intelligence (Lazear, 2004). Visuospatial thinking cannot be separated from the imagination process. According to Tabrani (2009) imagination is the process of learning, thinking and creating to form memory and increase knowledge. The Wimba learning model, in addition to increasing students' achievement, also helps students develop spatial or spatial-visual intelligence.

Some researchers stated that poor representational competence is a barrier to learning the STEM. Mathematics, physics, chemistry, and biology lessons are identified as the main disciplines of STEM showing the most successful students of those who have representational competence. Visuospatial representation competence is also important in studying biology, especially microscopic concepts such as bacteria, fungi, cells, tissues, organs, etc. The plant anatomy course learns about the structure and functions (Beck, CB, 2010). Microscopic observation can be used to build the cell, tissue and plant organ from $2 \mathrm{D}$ images into $3 \mathrm{D}$ designs. In addition to recognizing the $3 \mathrm{D}$ form, the learning could make students easily correlate the form and function of these cells. This process is referred to as mental processes, thought processes, imagination processes that can stimulate brain development to improve spatial ability or spatial intelligence.

The results of Suprapto (2012) showed that the wimba learning model could improve cognitive learning outcomes. A person is said to have good visual-spatial intelligence if $\mathrm{s} /$ he could answer cognitive questions easily by remembering the shape of figures (Lazear, 2004). Shepard (1978) stated that spatial imagination and visualization are essential for creativity and discovery. So it is believed that learning anatomy plants with wimba learning model has the opportunity to improve spatial intelligence, students' achievement, and creativity. Generally, school learnings are arranged with the deductive approach. The deductive approach carries out learning from general to specific or usually applied in combination with the teacher-centered learning, while the inductive approach brings learnings from specific to general (Atta, MA., M. Ayaz, Q. Nawaz, 2015). The late approach makes students more attractive in seeking their own information. Thus, it assumes that the inductive approach would further stimulate the brain to improve spatial intelligence, gain knowledge and enhance creativity.

Prior research shows that learning on plant anatomy using the visuospatial model (Wimba model) utilizing play dough media could enhance cognitive learning outcomes on the deductive approach, and result in a better understanding of the inductive approach. (Suprapto, 2012). While the results of Suprapto's research (2016) show that Wimba learning model can improve cognitive development and reasoning, especially proportional, correlational and combinatorial reasoning. The correlational and combinatorial reasoning, which is is the ability to correlate and make the combination of several variables, concern with creativity. Hence, these reasoning skills foster one's creativity to find a variety of alternative solutions for life and innovation to make products.

With this in mind, this study intends to identify the roles of visuospatial-based wimba learning model in developing spatial intelligence and students' achievement to support creativity in deductive and inductive approach. Information on the results of this study is important as a reference in implementing effective learning model to improve students' achievement, spatial intelligence, and develop creativity. 


\section{METHODS}

The research method employed in this research was the quantitative/quasi-experiment with the pre-post test group design. The research population was 4 th-semester Biology students in 4 classes of 135 students at a university in small town, West Java, Indonesia. The research sample was two classes having relatively the equal ability, picked with purposive sampling. The learning process was carried out using the deductive and inductive approach. The first class applied the deductive approach and the inductive approach for another.

The deductive approach steps started from 1) theory learning that is a) creating concept map created before learning; b) discussion; c) making tentative hypotheses about learned concepts. The next stage was: 2) the laboratory activity, starting from a) microscopic observation (observation of plant cells microscopically); b) representing the observation results of cells or plant tissues in the form of 2D images; c) designing cell or plant tissue images in $3 \mathrm{D} ; \mathrm{d}$ ) creating the $3 \mathrm{D}$ using 3DsMax software; e) discussing the practical results; f) confirmation. On the other side, the learning process Wimba learning process with the inductive approach began with 1) laboratory work and followed by 2) theories (figure1).

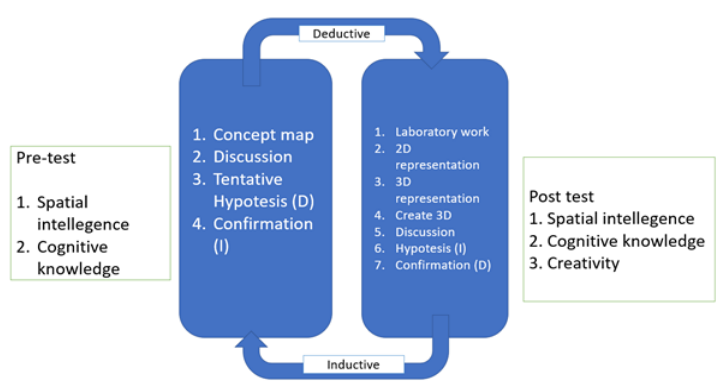

Figure 1. The Wimba Learning Steps with Deductive (D) and Inductive (I) Approach

The research instrument for the measurement of the students' achievement was the multiple choice test of on plant tissue and organ material, and the spatial intelligence was measured by adopting the spatial intelligence test based on Thorndike \& Lohman (1990) while the creativity was measured by employing the Test of Creativity Imagery Abilities or TCIA (Jankowska and M. Karwowski, 2015). Furthermore, the learning outcomes were processed using the N-Gain formula of Hake (1998).

To see the correlation between spatial intelligence and students' achievement on creativity with Wimba learning model, the test of students' achievement was done before and after research, while the test for spatial intelligence and creativity was carried out after learning. The data were proceeded using correlation test (multivariate)on SPSS (Fraenkel and Wallen, 2009).

\section{RESULTS AND DISCUSSION}

The research results of wimba learning model with deductive approach present that the average creativity of TCIA $=10.94$ and 2.51 of the deviation standard. Whereas the learning results $(\mathrm{n}$-Gain) $=0.47$ which belonged to the moderate category and the standard deviation of 0,16 . In addition, the spatial intelligence $=11.91$ and the standard deviation of 2,275 (Table 1).

Table 1. The Average Results of Spatial Intelligence and Learning Outcomes on Deductive and Inductive Approaches (n-34)

\begin{tabular}{|c|c|c|c|c|}
\hline & \multicolumn{4}{|c|}{ Descriptive Statistics } \\
\hline & \multicolumn{2}{|c|}{ Deductive } & \multicolumn{2}{|c|}{ Inductive } \\
\hline & Mean & SD & Mean & SD \\
\hline $\begin{array}{l}\text { Spacial intel- } \\
\text { ligence }\end{array}$ & 11,91 & 2,275 & 8,26 & 3,93 \\
\hline $\begin{array}{l}\text { Students' } \\
\text { achievement }\end{array}$ & 0,467 & 0,165 & 0,52 & 0,14 \\
\hline Creativity & 10,94 & 2,51 & 12,82 & 1,91 \\
\hline
\end{tabular}

'The computation results of correlation test of spatial intelligence and students' achievement toward creativity, simultaneously state that there was a significant relation between spatial intelligence and learning result toward creativity. The correlation coefficient $(\mathrm{R})$ of 0.451 shows the category of medium relations and the coefficient of determination (r) of 0.203 or $20.3 \%$ at a significance level of $0.030<0.05$.

In addition, only spatial intelligence had a significant relationship with creativity at the sig. level of $0.011<0.05$. The regression equation was $\mathrm{Y}=6,950-3,146 \mathrm{X} 1+0,489 \mathrm{X} 2$.

The research results of wimba model with inductive approach show that the average of spatial intelligence $=8.26$ and the standard deviation of 3,93 . Whereas the students' achievement $=0,52$, which categorized as moderate, and the standard deviation of 0,14 . Moreover,the creativity of TCIA $=18,82$ and the standard deviation of 1,91 (Table 1 ).

The calculation results of the correlation test simultaneously show that there was a signifi- 
cant relation between spatial intelligence and learning results toward creativity with the correlation coefficient $(R)=0,474$, categorized as medium and the coefficient of determination $(\mathrm{r})=0,225$ or $22,5 \%$ at a significance level of $0.019<0.05$. Partially, both spatial intelligence and students' achievement correlated significantly with creativity at the significance level of 0.021 and 0.017 $<0.05$. The regression equation is $\mathrm{Y}=14,090$ $5,753 \times 1+0,210 \times 2$

The learning process using the wimba model shows that the deductive and inductive approach is capable of supporting creativity at the moderate level, seen from the results of correlation test that there was a significant relationship between spatial intelligence and students' achievement on creativity in both approaches. The implementation 3D courses had a positive impact on students' success (Sorby, F2009). In the deductive approach, only spatial intelligence had a significant relationship with creativity. This is in contrast with the inductive approach in which both spatial intelligence and students' achievement correlated significantly with creativity. This suggests that only spatial intelligence supports creativity in the deductive approach, while the students' achievement and spatial intelligence supports creativity in the inductive approach. Therefore, the inductive method is better than the deductive for teaching mathematics (Atta, MA., M. Ayaz, Q. Nawaz (2015) The deductive approach could better develop spatial intelligence. The deductive learning started from concept map, discussion (lecture/theory) and 3D microscopic representation (Figure. 2). The $3 \mathrm{D}$ representation activity in a lab was successful after the lecture has been able to encourage students and improve their achievement at the moderate level. On the other side, the inductive learning started with understanding concepts in $3 \mathrm{D}$ representation done in a lab. After that, lecturing was performed in a classroom. These activities positively motivated the students to learn independently resulting in the students' creative works. Kurnik (2008), said that teachers should raise students' curiosity and show them the way to new innovations in accordance with the inductive method.

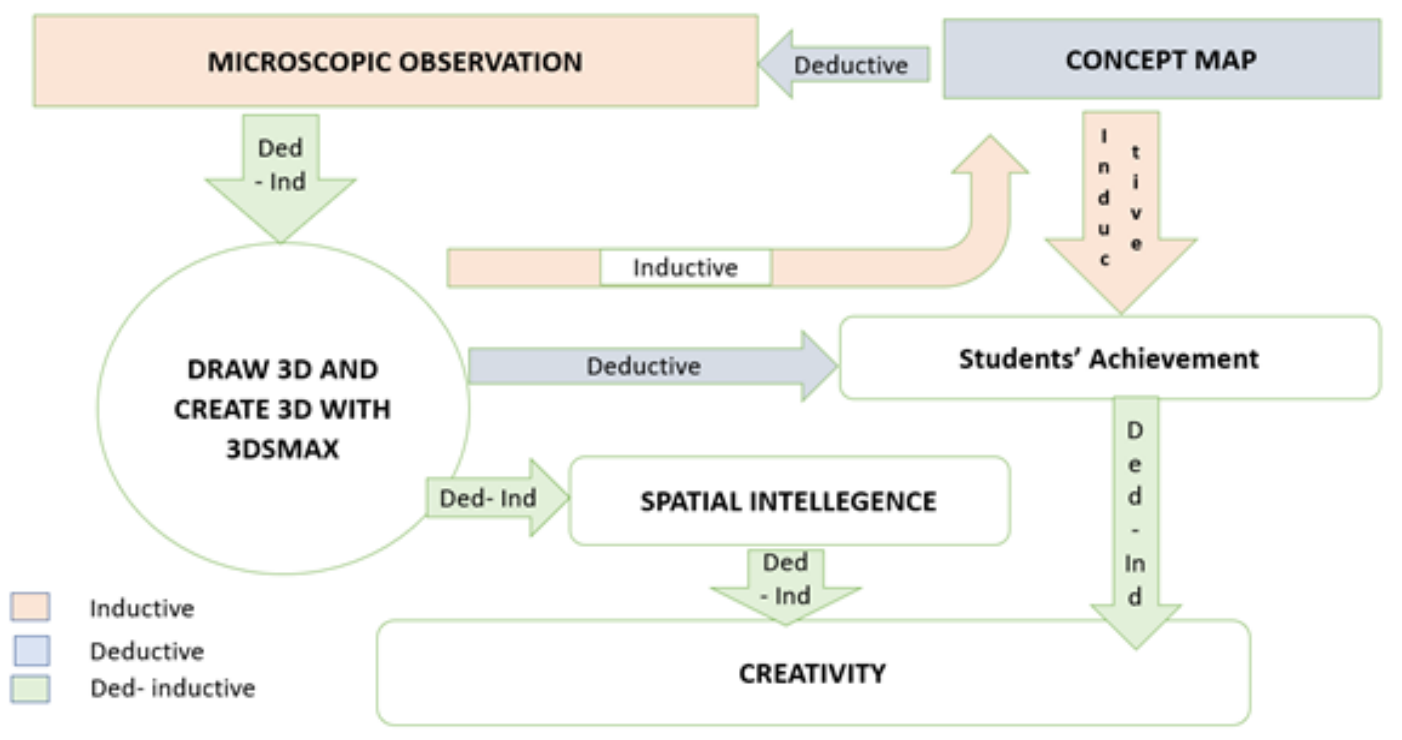

Figure 2. The Research Flowchart

\section{Spatial Intelligence}

Spatial intelligence defines as the ability to generate, retain, retrieve, and alter structured visual images well (Thorndike \& Lohman, 1990). Spatial skills emphasize different aspects of the process of image creation, storage, retrieval, and transformation. Spatial skills is an important construction of all models of human capability. Everyone needs spatial intelligence for everyday life. This intelligence is very helpful for a per- son not to get lost or lose direction. For instance, when we arrive in a city that has a relatively similar building, housing, or even when getting into the forest at mountain climbing. The spatial intelligence trains a person to be able to estimate space $s /$ he needs in order not to touch others while walking or driving. Lately, people forget the importance of developing the space intelligence since it is not considered important. In fact, someone with vigorous spatial intelligence usually 
has a better mathematical ability and is faster in decision making. Several studies have shown that spatial intelligence indicates gender. Usually, men have better spatial intelligence and women have better verbal skills as boys generally play outside (outdoor) with games that train their spatial intelligence just as playing ball, playing basketball, marbles, and others. The deductive approach in the wimba learning model was able to develop better spatial abilities than the inductive. The process, which began with concept mapmaking followed by a $3 \mathrm{D}$ representation through microscopic representation, has been able to stimulate better spatial abilities. The result of the average space intelligence test on the deductive approach was 11.91 , while the inductive approach was 8.26 (Table 1). On the contrary, the deductive learning starts from general to special, from abstract to concrete, while spatial intelligence does not obtain through repetition or drilling (Atta, 2015). The students learned using the deductive approach were livelier during the observation since they have understood the concepts and knew the cell shape before microscopic observation. This made it easier for the students to observe, draw cell shapes, and allow them to create concrete 3D shapes on 3DsMax software. This process could improve their spatial intelligence.

\section{Students' Achievement Improvements}

The visuospatial-based of Wimba learning led the students to learn the concept of plant anatomy in detailed 3D, while the task of creating a concept map confirms that the students comprehended deeply the plant anatomy concepts (Figure 2). This was proven to have an impact on cognitive learning outcomes. Mei Lu, F., et al., (2008) conducted the research on the use of transparency embryo models that seems to help students expand their view of embryonic development from two to three dimensions. Korakakis et al. (2009) and Hsiung \& Lai (2013), stated that 3D learning increase students' achievement and decrease cognitive load. Goldberg \& Dintzis (2007), found that there was an increase of 8-14 points on the identical final exam given over the last 5 years on inductive microscope-based virtual learning in physiology and histology.

The improvement of students' achievement in the deductive and inductive approach was favorable and categorized as 'moderate'. Thus, it indicates that the ability of visuospatial representation could improve the students' achie- vement in the 'moderate' category. The improved students' achievement were categorized according to Hake (1998).

An inductive approach is an approach beginning with certain or simple examples and concrete illustrations which leads to abstraction rules, general and complex. The inductive approach is well-suited for biological learning that starts from observations of concrete objects. The curiosity raised during an inductive learning may lead to in-depth learning and meaningful internalization processes (Atta, 2015). The low students' achievement likely occurred in deductive learning, showing that the Wimba learning is better if it is combined with the inductive approach.

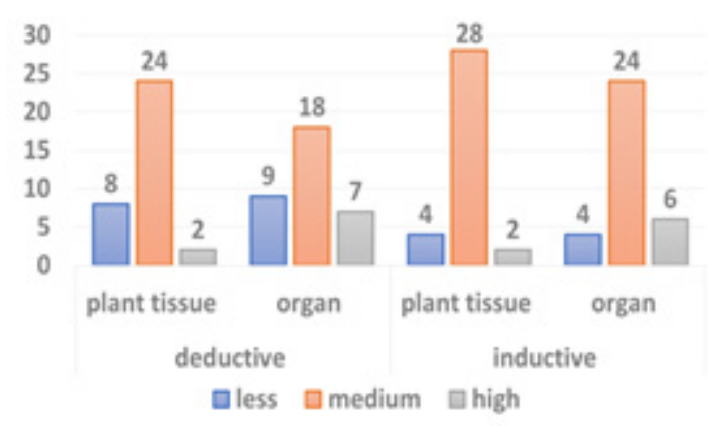

Figure 3: Students' Achievement Categories (Ngain) According to Meltzer (2002)

\section{Creativity}

In dealing with the $\mathrm{Z}$ and alpha generation or so-called as the digital generation, all teachers must prepare their students to increase creativity. In this digital era, workers compete with robots. Hence, when children are not equipped with creative thinking skills, they are unable to survive and lose the competition with robotic and digital devices. This model is prepared for children of robotics generation that are creative, active and fond of using virtual applications.

Creative people are those who can survive in the competition of life. To overcome this, the Wimba learning model is one solution that can train students to think creatively by doing a $3 \mathrm{D}$ representation and will have an impact on improving the creativity of students. Studente et al. (2016), stated that creativity is a specific domain and the steps taken practically to enhance creativity must be aligned with the target domain

The Test of Creativity Imagery Ability (TCIA), is a way of measuring creative visual imagination, reconciling research of creativity and imagination, and presenting a new psycho- 
metric instrument (Jankowska \& Karwowski, 2015). Creative imagination consists of three interrelated components: clarity, originality, and transformation. TCIA is suitable for this study as the Wimba learning model also involves three components of creating images with a high degree of complexity and detail (clarity), resulting in a unique (originality) and transformative image (controlling change of shape). The wimba learning model also uses imagination when representing $3 \mathrm{D}$ with a high level of complexity and detail. The hectic activities are to represent the results of microscopic observations from $2 \mathrm{D}$ images into $3 \mathrm{D}$. This imaginative mental activity is able to stimulate the brain's creativity.

The results show that wimba learning model with inductive approach was able to develop creativity better than the deductive approach. The inductive learning which began with microscopic observations has made them more creative.

\section{The Correlation of Spatial Intelligence and Students' Achievement on Creativity}

The visuospatial-based model of Wimba learning, particularly in the inductive learning, supported students' achievement and creativity. Davis \& Rimm (2004), stated that a student's creativity can be stimulated by assigning tasks that involve convergent and divergent thinking. Creativity could also depend more on the domain-specific cognitive skills, such as visuospatial abilities, or verbal skills (Palmiero et al., 2010). Palmiero et al. (2015) stated that the linkage between the spatial ability components of visualization has a role in promoting creativity. Imagining the spatial shape by transforming it into $2 \mathrm{D}$ and $3 \mathrm{D}$ form before matching to other spatial forms enable one to develop creative ideas. The inductive learning done in this research started with microscopic observation, 2D image representation and then rotating to create $3 \mathrm{D}$ image design, and $3 \mathrm{D}$ concrete with 3DsMax (Figure 4 and 5). It continued with concept maps, which had a better impact on the students' achievement and creativity. The cognitive process of the inductive approach was an in-depth learning process through meaningful internalization. Such cognitive processes helped students to incorporate ideas so as to make them perceived more solutions or ideas. This is in line with the findings of Fatimah, (2015), Nuswowati \& Taufiq (2015), Nuswowati et al, (2017) who revealed that creativity would improve when someone is facing a problem since s/he would think of various solutions that make her/him more creative.
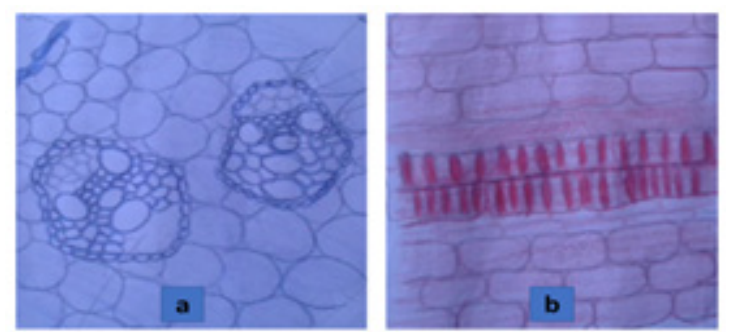

Figure 4. 2D Picture of a) the Transverse Incision and $b$ ) the Longitudinal Incision of Zea mays stem (400x)
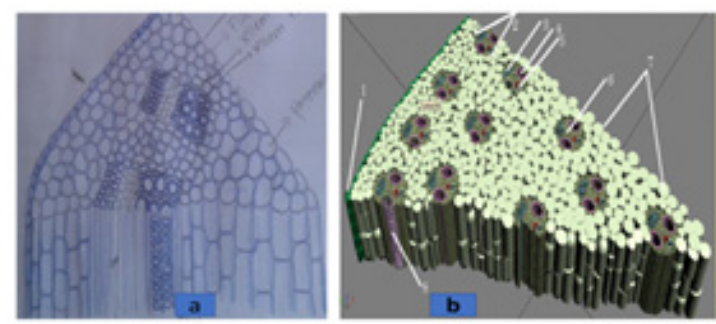

Figure 5. a) 3D Design and b) 3D Design Using 3DsMax

The calculation results of the correlation test simultaneously indicate that there was a relationship between spatial intelligence and students' achievement on creativity in the inductive approach. The correlation show a moderate relationship ( $\mathrm{R}=0.474)$. However, partially, spatial intelligence and students' achievement had a significant relationship with creativity. Thus, the results of this study convinced that the Wimba learning model in the inductive approach was more effective in improving spatial intelligence, students' achievement, and creativity.

The overall multivariate correlation test computation of the Wimba learning model with deductive approach shows that there was a significant relationship between spatial intelligence and students' achievement on creativity at the moderate relationship category $(R=0.451)$. Therefore, the Wimba learning model on the deductive approach, spatial intelligence, and students' achievement could influence creativity at the moderate level. The results of partial calculation tell that only spatial intelligence having a significant relationship with creativity at the significance level of $0,011<0,05$. This suggests that spatial intelligence has a stronger relationship to enhance creativity in the deductive approach.

Spatial transformation places heavy demands on working memory so that spatial tests frequently show high correlation with general ability tests. Thus, the spatial ability could support higher-order thinking in Science and Maths. Palmiero et al. (2010) said that creativity depends more on the domain-specific cognitive skills, such 
as visuospatial abilities and verbal ability. In addition, presentation and discussion of visual-spatial results conducted in this research provided linguistic experiences to the students. Thorndike \& Lohman (1990) stated that the ability to produce visual-spatial models coordinated with linguistic inputs will have a broad impact on all stages of cognition. Individuals achieving a high score on the ability to create and manipulate such models are likely to succeed in jobs requiring the spatial skills, also, tend to produce such models spontaneously during their thinking process. However, if their verbal fluency is relatively low, they become more introverted.

\section{CONCLUSION}

It concludes that the Wimba learning model, i.e. the visuospatial- based microscopic representation learning model on deductive and inductive approach shows that there was a relationship between spatial intelligence and students' achievement on creativity, which categorized as the moderate relationship. It means that spatial intelligence and students' achievement learning outcomes can support creativity. The inductive Wimba learning model was more effective in improving spatial intelligence, students' achievement, and creativity. Nevertheless, the deductive approach in this research could increase spatial intelligence better.

\section{ACKNOWLEDGMENTS}

We would like to thank the LPPM of Siliwangi University which has given an opportunity to the researchers by giving the fund (DIPA) to carry out this research. The researchers believe that this learning model is useful for future generations, i.e. the active and creative robotic generation who fond of virtual applications.

\section{REFERENCES}

Atta, M. A., Ayaz, M., \& Nawaz, Q. (2015). Comparative Study Of Inductive \& Deductive Methods Of Teaching Mathematics At Elementary Level. Gomal University Journal of Research [GUJR], $31(1)$.

Beck, CB (2010), An Introduction to plat Structure abd Development : Plant Anatomy for the twenty-First Century, $2^{\text {nd }}$ ed, New York : Cambridge University Press.

Davis, GA and S.G.Rimm, (2004). Education of the Gifted and Talented, Mexico : Pearson/A and B

Fatimah, S. (2015). Devoting to Enhance the Critical
Thinking Skill and the Creativity of Students in Seventh Grade Through PBL Model with JAS Approachment. Jurnal Pendidikan IPA Indonesia (JPII), 4(2), 149-157.

Franenkel, J. R., \& Wallen, N. E. (2009). How to Design and Evaluate Researech Ineducation.

Goldberg, H. R., \& Dintzis, R. (2007). The Positive Impact of Team-Based Virtual Microscopy on Student Learning in Physiology and Histology. Advances in Physiology Education, 31(3), 261-265.

Hake, R. R. (1998). Interactive-Engagement vs. Traditional Methods: A Six-Thousand-Student Survey of Mechanics Test Data for Introductory Physics Courses. Arlington, VA: National Science Foundation.

Hsiung, L. Y., \& Lai, M. H. (2013). Improving Learning Results and Reducing Cognitive Load through 3D Courseware on Color Management and Inspection Instruction. Turkish Online Journal of Educational Technology-TOJET, 12(3), 91-106.

Jankowska, D. M., \& Karwowski, M. (2015). Measuring Creative Imagery Abilities. Frontiers in Psychology, 6, 1591.

Jauk, E., Benedek, M., Dunst, B., \& Neubauer, A. C. (2013). The Relationship between Intelligence And Creativity: New Support for the Threshold Hypothesis by Means of Empirical Breakpoint Detection. Intelligence, 41(4), 212-221.

Kell, H. J., Lubinski, D., Benbow, C. P., \& Steiger, J. H. (2013). Creativity and technical Innovation: Spatial Ability's Unique Role. Psychological Science, 24(9), 1831-1836.

Korakakis, G., Pavlatou, E. A., Palyvos, J. A., \& Spyrellis, N. (2009). 3D Visualization Types in Multimedia Applications ior Science Learning: A Case Study for 8th Grade Students in Greece. Computers \& Education, 52(2), 390-401.

Kurnik, Z. (2008). The Scientific Approach to Teaching Math. Metodika: Casopis za teoriju i praksu metodikâ u predškolskom odgoju, školskoj i visokoškolskoj izobrazbi, S(17), 419-430.

Lazear, D. G. (2004). Higher-Order Thinking the Multiple Intelligences Way. Zephyr Press.

Lu, F. M., Eliceiri, K. W., Squirrell, J. M., White, J. G., \& Stewart, J. (2008). Student Learning of Early Embryonic Development Via the Utilization of Research Resources from the Nematode Caenorhabditis Elegans. CBE-Life Sciences Education, 7(1), 64-73.

Milner-Bolotin, M., \& Nashon, S. M. (2012). The Essence of Student Visual-Spatial Literacy and Higher Order Thinking Skills in Undergraduate Biology. Protoplasma, 249(1), 25-30.

Nuswowati, M., \& Taufiq, M. (2015). Developing Creative Thinking Skills and Creative Attitude Through Problem Based Green Vision Chemistry Environment Learning. Jurnal Pendidikan IPA Indonesia, 4(2).

Nuswowati, M., Susilaningsih, E., Ramlawati, R., \& Kadarwati, S. (2017). Implementation of Problem-Based Learning with Green Chemistry 
Vision to Improve Creative Thinking Skill and Students' Creative Actions. Jurnal Pendidikan IPA Indonesia, 6(2), 221-228.

Palmiero, M., Nakatani, C., Raver, D., Belardinelli, M. O., \& van Leeuwen, C. (2010). Abilities within and across Visual and Verbal Domains: How Specific is Their Influence on Creativity? Creativity Research Journal, 22(4), 369-377.

Palmiero, M., Nori, R., Aloisi, V., Ferrara, M., \& Piccardi, L. (2015). Domain-Specificity of Creativity: A Study on the Relationship Between Visual Creativity and Visual Mental Imagery, Frontiers in Psychology, 6, 1870.

Ramadas, J. (2009). Introduction to the Special Issue on "Visual and Spatial Modes in Science Learning".

Shepard, R. N. (1978). Externalization of mental images and the act of creation. In B. S. Randhawa \& W. E. Coffman (Eds.), Visual learning, thinking, and communication (pp. 133-190). New York: Academic Press

Sorby, S.A, (2009), Educational Research in Developing 3-D Spatial Skill form Engineering Student. International Journal of Science Education, 3(3), 459-480.

Stieff, M., Scopelitis, S., Lira, M. E., \& Desutter, D. (2016). Improving Representational Compe- tence with Concrete Models. Science Education, $100(2), 344-363$.

Studente, S., Seppala, N., \& Sadowska, N. (2016). Facilitating Creative Thinking in the Classroom: Investigating the Effects of Plants and the Colour Green on Visual and Verbal Creativity. Thinking Skills and Creativity, 19, 1-8.

Suprapto, P. K. (2012). Pengembangan Program Perkuliahan Anatomi Tumbuhan Berbasis Visuospasial Melalui Representasi Mikroskopis Sistem Jaringan Tumbuhan untuk Meningkatkan Penalaran dan Penguasaan Konsep Calon Guru Biologi. Bandung Indonesia: Disertation, Universitas Pendidikan Indonesia.

Suprapto, P. K. (2017). Pengaruh Model Wimba Menggunakan Media 3Dsmax Terhadap Hasil Belajar Dan Penalaran Logis Mahasiswa Calon Guru Biologi. Jurnal Pengajaran MIPA, 21(2).

Tabrani, P. (2009). Wimba, Asal Usul dan Peruntukkannya. WIMBA-Jurnal Komunikasi Visual, 1(1), 1-7.

Thorndike, R. M., \& Lohman, D. F. (1990). A Century of Ability Testing. Riverside Publishing Company. 